\title{
Fetal and infant growth and impaired glucose tolerance at age 64/
}

C N Hales, D J P Barker, P M S Clark, L J Cox, CFall, C Osmond, P D Winter

Abstract

Objective-To discover whether reduced fetal and infant growth is associated with non-insulin dependent diabetes and impaired glucose tolerance in adult life.

Design-Follow up study of men born during 1920-30 whose birth weights and weights at 1 year were known.

Setting-Hertfordshire, England.

Subjects -468 men born in east Hertfordshire and still living there.

Main outcome measures-Fasting plasma glucose, insulin, proinsulin, and $32-33$ split proinsulin concentrations and plasma glucose and insulin concentrations 30 and 120 minutes after a 75 g glucose drink.

Results -93 men had impaired glucose tolerance or hitherto undiagnosed diabetes. They had had a lower mean birth weight and a lower weight at 1 year. The proportion of men with impaired glucose tolerance fell progressively from $26 \%(6 / 23)$ among those who had weighed $18 \mathrm{lb}(8.16 \mathrm{~kg})$ or less at 1 year to $13 \%$ (3/24) among those who had weighed $27 \mathrm{lb}(12 \cdot 25$ $\mathrm{kg}$ ) or more. Corresponding figures for diabetes were $17 \%(4 / 23)$ and nil (0/24). Plasma glucose concentrations at 30 and 120 minutes fell with increasing birth weight and weight at 1 year. Plasma 32-33 split proinsulin concentration fell with increasing weight at 1 year. All these trends were significant and independent of current body mass. Blood pressure was inversely related to birth weight and strongly related to plasma glucose and 32-33 split proinsulin concentrations.

Conclusions-Reduced growth in early life is

Department of.Clinical Biochemistry, (University of Cambridge, Addenbrooke's Hospital, Cambridge) CB2 2QR

C N Hales, FRCP, professor of clinical biochemistry

P M S Clark, PHD, principal biochemist

L J Cox, MSC, research

assistant

MRC Environmental Epidemiology Unit, Southampton General Hospital, Southampton SO9 4XY

D J P Barker, FRCP, professor and director

C Fall, MRCP, clinical research fellow

C Osmond, PHD, statistician

P D Winter, MSC,

computing manager

Correspondence to:

Professor Hales.

BMF 1991;303:1019-22 may be another link as it is a known risk factor for ischaemic heart disease, ${ }^{3}$ and non-insulin dependent diabetes is associated with hypertension. ${ }^{4}$ We therefore examined a sample of the men born in Hertfordshire and measured their glucose tolerance.

There is controversy about the relative importance of insulin deficiency due to pancreatic $\beta$ cell dysfunction and insulin resistance in the genesis of impaired glucose tolerance and non-insulin dependent diabetes. Recent advances in assay methodology make it possible to measure specifically plasma concentrations of insulin and its precursors, intact and 32-33 split proinsulin. ${ }^{5}$ People with non-insulin dependent diabetes have raised plasma concentrations of these precursors, which has been interpreted as evidence of $\beta$ cell dysfunction. ${ }^{6}$ We therefore measured insulin and its precursors in the Hertfordshire men to discover whether retarded early growth is linked to $\beta$ cell dysfunction.

\section{Subjects and methods}

In Hertfordshire from 1911 onwards each birth was notified by the attending midwife. A health visitor saw the child at home periodically throughout infancy and recorded birth weight and weight at 1 year. Weights were measured in pounds $(\mathrm{lb} ; 2 \cdot 2 \mathrm{lb}=1 \mathrm{~kg}$ ) and were often rounded to the nearest half pound or pound. We therefore used the original units. We traced singleton boys born in east Hertfordshire during 1920-30 who had both birth weight and weight at 1 year recorded. A total of 1157 of the men were still living there, and 845 of them agreed to be interviewed at home.

Each man was visited by one of four fieldworkers. The fieldworkers had not seen the infant data recorded for the man. Height was measured with a portable stadiometer and weight with a portable Seca scale. Waist circumference and hip girth were measured. Blood pressure was measured with an automated recorder (Dinamap) with the man sitting. Readings were taken on the left arm using the cuff size recommended for the arm circumference. Two readings were taken and the average used in the analysis. Room temperature was measured. The man was asked about his medical and social history. Father's occupation was used to define social class at birth, and current social class was derived from the man's occupation.? Before starting the study the procedures for the measurements were standardised and the fieldworkers trained.

After the interview the man was asked if he would be willing to attend a local clinic one morning after an overnight fast to have a standard $75 \mathrm{~g}$ oral glucose tolerance test. Men known to have diabetes were excluded. A total of 468 men agreed to attend the clinic and have a fasting blood sample taken; 408 had a full glucose tolerance test. Measurements on the blood $\stackrel{?}{?}$ samples included plasma glucose and insulin concentrations at zero, 30 , and 120 minutes and proinsulin and 32-33 split proinsulin concentrations at zero time 
only. Ethical approval was obtained from the east Hertfordshire ethics committee.

Plasma glucose was measured by a hexokinase method. ${ }^{8}$ Plasma insulin, proinsulin, and 32-33 split proinsulin concentrations were determined by two site immunometric assays with either iodine-125 or alkaline phosphatase as labels. ${ }^{59}$ The insulin assay was standardised against the first international reference preparation coded 66/304 and the intact and split proinsulin assays against standards obtained from Lilly Research Laboratories (Indianapolis, USA).

Because plasma measurements of glucose, insulin, proinsulin, and 32-33 split proinsulin have skewed distributions we transformed them to normality in the analysis by using logarithms. Values below the lower limit of detection were assigned the value of the lower limit. We analysed the data using linear regression, two sample $t$ tests and logistic regression for calculating odds ratios.

\section{Results}

The 468 men who attended the clinic fasting were aged 59-70 (mean 64) years. Of the 408 who had a glucose tolerance test, 370 had complete measurements on all blood samples. Our analysis is based on the 468 fasting blood samples and the 370 samples from complete glucose tolerance tests. Of the 370 men who had complete measurements on all samples, 66 had impaired tolerance, defined as a two hour plasma glucose concentration of $7 \cdot 8-11 \cdot 0 \mathrm{mmol} / \mathrm{l}$, and $27 \mathrm{had}$ diabetes, defined as a two hour plasma glucose concentration of $11.1 \mathrm{mmol} / \mathrm{l}$ or over. Compared with the 277 other subjects these men were on average $0.5 \mathrm{lb}$ $(227 \mathrm{~g})$ lighter at birth and $1.0 \mathrm{lb}(450 \mathrm{~g})$ lighter at 1 year (table I). They were heavier and had higher body mass indices (weight $(\mathrm{kg}) /(\text { height }(\mathrm{m}))^{2}$ ) and waist to hip ratios. They had higher systolic and diastolic blood pressures. Their fasting glucose concentrations were $1.0 \mathrm{mmol} / \mathrm{l}$ higher $(6.8 \mathrm{mmol} / \mathrm{l}$ compared with 5.8 $\mathrm{mmol} / \mathrm{l}$ ).

Men with impaired glucose tolerance or diabetes had higher mean insulin concentrations two hours after oral glucose $(284 \mathrm{pmol} / \mathrm{l}$ compared with $124 \mathrm{pmol} / \mathrm{l})$. They had higher mean fasting proinsulin concentrations $(4.06 \mathrm{pmol} / \mathrm{l}$ compared with $2.66 \mathrm{pmol} / \mathrm{l})$ and higher $32-33$ split proinsulin concentrations $(4.67 \mathrm{pmol} / 1$ compared with $2.72 \mathrm{pmol} / \mathrm{l})$. All these differences were significant at the $5 \%$ level.

Tables II and III show that the proportions of men with impaired glucose tolerance or diabetes fell progressively with increasing birth weight and weight at 1 year.

Tables IV and V show the trends with birth weight and weight at 1 year in glucose, insulin, and proinsulin concentrations and blood pressure. Each of these measurements varied with body mass index, which tended to increase with birth weight and weight at

TABLE I-Mean weight, height, body mass index, waist to hip ratio, and systolic and diastolic blood pressures in men with and without impaired glucose tolerance or newly diagnosed diabetes as defined by plasma glucose concentrations two hours after $75 \mathrm{~g}$ oral load

\begin{tabular}{|c|c|c|c|c|}
\hline & \multicolumn{2}{|c|}{$\begin{array}{c}\text { Two hour glucose } \\
\text { concentration }(\mathrm{mmol} / \mathrm{l})\end{array}$} & \multirow{2}{*}{$\begin{array}{c}\text { Difference ( } 95 \% \\
\text { confidence interval) }\end{array}$} & \multirow{2}{*}{$\begin{array}{c}\mathrm{p} \\
\text { Value }\end{array}$} \\
\hline & $<7 \cdot 8(\mathrm{n}=277)$ & $\geq 7 \cdot 8(\mathrm{n}=93)$ & & \\
\hline Birth weight $^{\star}\left\{\begin{array}{l}\mathrm{lb} \\
\mathrm{g}\end{array}\right.$ & $\begin{array}{l}8 \cdot 0 \\
3621\end{array}$ & $3411^{7 \cdot 5}$ & $\begin{array}{l}-0.5(-0 \cdot 8 \text { to }-0 \cdot 2) \\
-210(-351 \text { to }-69)\end{array}$ & 0.004 \\
\hline Weight at 1 year ${ }^{\star}\left\{\begin{array}{l}\mathrm{lb} \\
\mathrm{kg}\end{array}\right.$ & $\begin{array}{l}22 \cdot 8 \\
10 \cdot 3\end{array}$ & $\begin{array}{r}21 \cdot 8 \\
9 \cdot 9\end{array}$ & $\begin{array}{l}-1 \cdot 0(-1.6 \text { to }-0.3) \\
-0.4(-0.7 \text { to }-0.2)\end{array}$ & 0.002 \\
\hline $\begin{array}{l}\text { Height }(\mathrm{m}) \\
\text { Weight }(\mathrm{kg}) \\
\text { Body mass index }\left(\mathrm{kg} / \mathrm{m}^{2}\right) \\
\text { Waist to hip ratio } \\
\text { Systolic blood pressure }(\mathrm{mm} \mathrm{Hg}) \\
\text { Diastolic blood pressure }(\mathrm{mm} \mathrm{Hg})\end{array}$ & $\begin{array}{c}1 \cdot 72 \\
78 \cdot 5 \\
26 \cdot 6 \\
0 \cdot 93 \\
163 \\
89\end{array}$ & $\begin{array}{c}1 \cdot 71 \\
81 \cdot 7 \\
27 \cdot 9 \\
0 \cdot 95 \\
174 \\
92\end{array}$ & $\begin{array}{c}-0 \cdot 01(-0 \cdot 02 \text { to } 0 \cdot 01) \\
3 \cdot 2(0 \cdot 4 \text { to } 5 \cdot 9) \\
1 \cdot 4(0 \cdot 6 \text { to } 2 \cdot 2) \\
0 \cdot 02(0 \cdot 01 \text { to } 0 \cdot 03) \\
11(6 \text { to } 17) \\
3(0 \text { to } 6)\end{array}$ & $\begin{array}{c}0.21 \\
0.02 \\
0.001 \\
0.001 \\
<0.001 \\
0.02\end{array}$ \\
\hline
\end{tabular}

*Original measurements were expressed in pounds (lb) and were rounded.
TABLE II - Proportions of men aged 64 with impaired glucose tolerance or diabetes according to birth weight

\begin{tabular}{|c|c|c|c|c|c|c|}
\hline \multicolumn{2}{|c|}{ Birth weight ${ }^{\star}$} & \multirow{2}{*}{$\begin{array}{l}\text { No of } \\
\text { men }\end{array}$} & \multicolumn{3}{|c|}{$\begin{array}{l}\text { No }(\%) \text { of men with two hour } \\
\text { glucose }(\mathrm{mmol} / \mathrm{l}) \text { of: }\end{array}$} & \multirow{2}{*}{$\begin{array}{c}\text { Odds ratio } \\
\text { (95\% confidence } \\
\text { interval) } \dagger\end{array}$} \\
\hline $\mathrm{lb}$ & $\mathrm{g}$ & & $7 \cdot 8-11 \cdot 0$ & $\geqslant 11 \cdot 1$ & $\geqslant 7 \cdot 8$ & \\
\hline$\leq 5 \cdot 5$ & $\leqslant 2495$ & 20 & $6(30)$ & $2(10)$ & $8(40)$ & 5 to 28$)$ \\
\hline$-6 \cdot 5$ & -2948 & 47 & $10(21)$ & $6(13)$ & $16(34)$ & $4.8(1.3$ to \\
\hline$-7 \cdot 5$ & -34 & 104 & 26 & $6(6)$ & $32(31)$ & $4.6(1.4$ to \\
\hline$-8 \cdot 5$ & -3856 & 117 & $18(15)$ & $8(7)$ & $26(22)$ & $2.6(0.8$ to \\
\hline$-9 \cdot 5$ & -4309 & 54 & $2(4)$ & $5(9)$ & $7(13)$ & $1.4(0.3$ to 5.6$)$ \\
\hline$>9 \cdot 5$ & $>4309$ & 28 & $4(14)$ & 0 & $4(14)$ & $1 \cdot 0$ \\
\hline & & . & $66(18)$ & $27(7)$ & $93(25)$ & \\
\hline
\end{tabular}

Original measurements were expressed in $\mathrm{lb}$ and were rounded.

Original measurements were expressed in $\mathrm{lb}$ and were rounded. body mass index $\left(\chi^{2}\right.$ for trend $=15 \cdot 4 ; p<0 \cdot 001$ ).

TABLE III-Proportions of men aged 64 with impaired glucose tolerance or diabetes according to weight at 1 year

\begin{tabular}{|c|c|c|c|c|c|c|}
\hline \multicolumn{2}{|c|}{ Weight at 1 year } & \multirow{2}{*}{$\begin{array}{c}\text { No of } \\
\text { men }\end{array}$} & \multicolumn{3}{|c|}{$\begin{array}{l}\text { No (\%) of men with two hour } \\
\text { glucose }(\mathrm{mmol} / \mathrm{l}) \text { of: }\end{array}$} & \multirow{2}{*}{$\begin{array}{c}\text { Odds ratio } \\
\text { (95\% confidence } \\
\text { interval) })\end{array}$} \\
\hline $\mathrm{lb}$ & $\mathrm{kg}$ & & $7 \cdot 8-11 \cdot 0$ & $\geqslant 11 \cdot 1$ & $\geqslant 7.8$ & \\
\hline$\leq 18$ & $\leqslant 8 \cdot 16$ & 23 & $6(26)$ & $4(17)$ & $10(43)$ & $8.2(1.8$ to 38$)$ \\
\hline-20 & $-9 \cdot 07$ & 63 & $13(21)$ & $7(11)$ & $20(32)$ & $4.8(1.2$ to 19$)$ \\
\hline-22 & $-9 \cdot 98$ & 107 & $24(22)$ & $8(7)$ & $32(30)$ & $4 \cdot 2(1 \cdot 1$ to 16$)$ \\
\hline-24 & $-10 \cdot 89$ & 105 & $14(13)$ & $5(5)$ & $19(18)$ & $2 \cdot 1(0.5$ to 7.9$)$ \\
\hline-26 & $-11 \cdot 79$ & 48 & $6(13)$ & $3(6)$ & $9(19)$ & $2 \cdot 1(0.5$ to 9.0$)$ \\
\hline$\geqslant 27$ & $\geqslant 12.25$ & 24 & $3(13)$ & 0 & $3(13)$ & $1 \cdot 0$ \\
\hline otal & & 370 & $66(18)$ & $27(7)$ & $93(25)$ & \\
\hline
\end{tabular}

* Original measurements were expressed in $\mathrm{lb}$ and were rounded. tOdds ratio for two hour glucose of $\geqslant 7.8 \mathrm{mmol} / \mathrm{l}$ adjusted for body mass index $\left(\chi^{2}\right.$ for trend $=14.9 ; \mathrm{p}<0.001$ ).

year, though the trends were weak. We therefore allowed for body mass index when calculating the significance of trends with early weight. Plasma glucose concentration at two hours fell with increasing birth weight and weight at 1 year (tables IV and V). Plasma glucose concentration at 30 minutes showed similar trends. Fasting plasma glucose values showed no trends. Table VI shows the plasma glucose concentrations at two hours with the men divided into approximate thirds according to weight at 1 year and adult body mass index. The values rose from $5.8 \mathrm{mmol} / 1$ in men with the highest weights at 1 yea and lowest body mass indices to $7.7 \mathrm{mmol} / 1$ in men with the lowest weights at 1 year and highest body mass indices.

Similarly to plasma glucose, plasma insulin concentrations at two hours fell with increasing birth weight and weight at 1 year (tables IV and V). Thirty minute and fasting plasma insulin values showed no trends with early weights.

Plasma proinsulin concentrations showed no trend with either birth weight or weight at 1 year. Plasma 3233 split proinsulin concentrations fell slightly with increasing birth weight but showed a strong downward trend with increasing weight at 1 year (tables IV and V). Table VII shows the plasma 32-33 split proinsulin concentrations with the men divided into approximate thirds according to weight at 1 year and adult body mass index. The values rose from $2 \cdot 1 \mathrm{pmol} / 1$ in men with the highest weights at 1 year and lowest body mass indices to $4.8 \mathrm{pmol} / 1$ in men with the lowest weights at 1 year and highest body mass indices.

Systolic blood pressure fell with increasing birth weight and weight at 1 year (tables IV and V). The trend with weight at 1 year was abolished by adjustment for birth weight. Systolic pressure rose with increasing plasma glucose concentration at two hours $(p=0.02)$ independently of body mass index. The trend with plasma glucose concentration at 30 minutes was stronger $(p=0 \cdot 0006)$. Systolic pressure also rose with increasing plasma 32-33 split proinsulin concentration $(p=0.005)$, again independently of body mass index. Diastolic pressure varied with plasma glucose

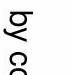

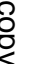

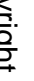
(n) 
and proinsulin concentrations in the same way as systolic pressure, but the trends were weaker.

The men's social class either at birth or currently was not related to plasma glucose, insulin, or proinsulin concentration. Adjustment for social class did not change the associations with birth weight and weight at 1 year.

\section{Discussion}

In this study of men aged $59-70,18 \%(66 / 370)$ were found to have impaired glucose tolerance and 7\% (27/ 370) were newly discovered diabetics. These figures are consistent with other surveys. ${ }^{10}$ Our study shows that adults with impaired glucose tolerance and noninsulin dependent diabetes have lower weight gain prenatally and during infancy. The proportion of men with impaired glucose tolerance and diabetes fell progressively up to the highest values of birth weight and weight at 1 year (tables II and III). There were threefold differences in the prevalence of impaired tolerance and diabetes between men with the lowest and highest early weights. These trends paralleled the fall in death rates from ischaemic heart disease with increasing birth weight and weight at 1 year which we described recently. ${ }^{\prime}$ They suggest that impaired glucose tolerance and ischaemic heart disease may both be determined by influences which reduce fetal and infant growth.

Tables VI and VII illustrate how fetal and infant growth protect against the deleterious effect of higher body mass in adult life and, conversely, how lower body mass protects against the deleterious effect of reduced early growth. Twenty six per cent of men $(14 / 53)$ whose birth weights and weights at 1 year were below the median and whose body mass indices were

TABLE IV-Mean body mass index; geometric mean plasma glucose, insulin, and proinsulin concentrations; and mean systolic blood pressure according to birth weight

\begin{tabular}{|c|c|c|c|c|c|c|c|c|}
\hline & \multicolumn{8}{|c|}{ Birth weight in $\mathrm{lb}(\mathrm{g})^{\star}$} \\
\hline & $\begin{array}{c}\leq 5 \cdot 5 \\
(\leqslant 2495)\end{array}$ & $\begin{array}{c}-6 \cdot 5 \\
(-2948)\end{array}$ & $\begin{array}{c}-7 \cdot 5 \\
(-3402)\end{array}$ & $\begin{array}{c}-8 \cdot 5 \\
(-3856)\end{array}$ & $\begin{array}{c}-9 \cdot 5 \\
(-4309)\end{array}$ & $\begin{array}{c}>9 \cdot 5 \\
(>4309)\end{array}$ & All & $\begin{array}{l}\text { Trend } \\
\text { test } \dagger\end{array}$ \\
\hline \multicolumn{9}{|l|}{ Fasting blood samples: } \\
\hline No of men & 21 & 61 & 144 & 141 & 68 & 33 & 468 & \\
\hline Body mass index $\left(\mathrm{kg} / \mathrm{m}^{2}\right)$ & $26 \cdot 7$ & $26 \cdot 8$ & $26 \cdot 4$ & $26 \cdot 9$ & $26 \cdot 8$ & $29 \cdot 1$ & $26 \cdot 9$ & \\
\hline Glucose $(\mathrm{mmol} / \mathrm{l})$ & $6 \cdot 2$ & $6 \cdot 0$ & $6 \cdot 1$ & $6 \cdot 1$ & $6 \cdot 0$ & $5 \cdot 8$ & $6 \cdot 1$ & $0 \cdot 17$ \\
\hline Insulin ( $\mathrm{pmol} / \mathrm{l})$ & 45 & 44 & 41 & 41 & 40 & 46 & 42 & $0 \cdot 15$ \\
\hline Proinsulin (pmol/l) & 3.5 & $2 \cdot 8$ & $3 \cdot 0$ & $3 \cdot 0$ & $2 \cdot 9$ & $2 \cdot 9$ & $3 \cdot 0$ & $0 \cdot 24$ \\
\hline 32-33 Split proinsulin $(\mathrm{pmol} / \mathrm{l})$ & 3.6 & $3 \cdot 4$ & $3 \cdot 0$ & $3 \cdot 1$ & $3 \cdot 0$ & $3 \cdot 1$ & $3 \cdot 1$ & 0.06 \\
\hline Systolic blood pressure $(\mathrm{mm} \mathrm{Hg})$ & 173 & 165 & 166 & 164 & 161 & 161 & 164 & 0.001 \\
\hline \multicolumn{9}{|l|}{ Glucose tolerance tests: } \\
\hline No of men & 20 & 47 & 104 & 117 & 54 & 28 & 370 & \\
\hline \multirow{3}{*}{ Glucose $(\mathrm{mmol} / \mathrm{l})\left\{\begin{array}{c}30 \text { minute } \\
2 \text { hours }\end{array}\right.$} & $10 \cdot 1$ & $9 \cdot 9$ & $9 \cdot 7$ & $9 \cdot 3$ & $9 \cdot 2$ & $8 \cdot 9$ & $9 \cdot 5$ & $0 \cdot 001$ \\
\hline & $7 \cdot 5$ & 6.9 & $6 \cdot 8$ & $6 \cdot 5$ & $6 \cdot 3$ & $5 \cdot 9$ & $6 \cdot 6$ & $0 \cdot 002$ \\
\hline & 315 & 293 & 254 & 282 & 248 & 296 & 273 & 0.22 \\
\hline Insulin $(\mathrm{pmol} / \mathrm{l})\left\{\begin{array}{c}30 \text { minutes } \\
2 \text { hours }\end{array}\right.$ & 224 & 192 & 161 & 139 & 124 & 143 & 153 & 0.0005 \\
\hline
\end{tabular}

*Original measurements were expressed in $\mathrm{lb}$ and were rounded.

tp Value adjusted for body mass index.

TABLE V-Mean body mass index; geometric mean plasma glucose, insulin, and proinsulin concentrations; and mean systolic blood pressure according to weight at 1 year

\begin{tabular}{|c|c|c|c|c|c|c|c|c|}
\hline & \multicolumn{8}{|c|}{ Weight at 1 year in $\mathrm{lb}(\mathrm{kg})^{\star}$} \\
\hline & $\begin{array}{c}\leq 18 \\
(\leq 8 \cdot 16)\end{array}$ & $\begin{array}{c}-20 \\
(-9 \cdot 07)\end{array}$ & $\begin{array}{c}-22 \\
(-9 \cdot 98)\end{array}$ & $\begin{array}{c}-24 \\
(-10 \cdot 89)\end{array}$ & $\begin{array}{c}-26 \\
(-11 \cdot 79)\end{array}$ & $\begin{array}{c}\geqslant 27 \\
(\geqslant 12 \cdot 25)\end{array}$ & All & $\begin{array}{l}\text { Trend } \\
\text { test } \dagger\end{array}$ \\
\hline \multicolumn{9}{|l|}{ Fasting blood samples: } \\
\hline No of men & 28 & 75 & 143 & 132 & 63 & 27 & 468 & \\
\hline Body mass index $\left(\mathrm{kg} / \mathrm{m}^{2}\right)$ & $26 \cdot 2$ & $26 \cdot 4$ & $26 \cdot 9$ & $26 \cdot 9$ & $26 \cdot 9$ & $28 \cdot 3$ & $26 \cdot 9$ & \\
\hline Glucose $(\mathrm{mmol} / \mathrm{l})$ & 6.0 & $6 \cdot 1$ & $6 \cdot 1$ & $6 \cdot 1$ & 6.0 & $5 \cdot 8$ & $6 \cdot 1$ & $0 \cdot 2$ \\
\hline Insulin (pmol/l) & 34 & 49 & 43 & 38 & 42 & 43 & 42 & $0 \cdot 11$ \\
\hline Proinsulin $(\mathrm{pmol} / \mathrm{l})$ & $3 \cdot 1$ & $2 \cdot 9$ & $3 \cdot 1$ & $2 \cdot 8$ & $3 \cdot 3$ & $2 \cdot 7$ & $3 \cdot 0$ & 0.11 \\
\hline 32-33 Split proinsulin $(\mathrm{pmol} / \mathrm{l})$ & $3 \cdot 4$ & $3 \cdot 3$ & $3 \cdot 2$ & $2 \cdot 8$ & $3 \cdot 4$ & $2 \cdot 5$ & $3 \cdot 1$ & 0.008 \\
\hline Systolic blood pressure (mm Hg) & 168 & 169 & 165 & 162 & 162 & 161 & 164 & 0.007 \\
\hline \multicolumn{9}{|l|}{ Glucose tolerance tests: } \\
\hline No of men & 23 & 63 & 107 & 105 & 48 & 24 & 370 & \\
\hline \multirow{2}{*}{ Glucose $(\mathrm{mmol} / \mathrm{l})\left\{\begin{array}{l}30 \text { minutes } \\
2 \text { hours }\end{array}\right.$} & $9 \cdot 7$ & $9 \cdot 7$ & $9 \cdot 8$ & $9 \cdot 4$ & $9 \cdot 0$ & $8 \cdot 7$ & $9 \cdot 5$ & 0.004 \\
\hline & $7 \cdot 9$ & $7 \cdot 0$ & 6.7 & $6 \cdot 5$ & $6 \cdot 3$ & $6 \cdot 0$ & $6 \cdot 6$ & 0.0006 \\
\hline \multirow{2}{*}{ Insulin $(\mathrm{pmol} / \mathrm{l})\left\{\begin{array}{l}30 \text { minutes } \\
2 \text { hours }\end{array}\right.$} & 220 & 286 & 290 & 279 & 253 & 238 & 273 & $0 \cdot 16$ \\
\hline & 153 & 201 & 156 & 138 & 129 & 144 & 153 & 0.002 \\
\hline
\end{tabular}

$\star$ Original measurements were expressed in $\mathrm{lb}$ and were rounded.

tp Value adjusted for body mass index.
TABLE VI-Geometric mean plasma glucose concentration (mmol/l) two hours after $75 \mathrm{~g}$ oral glucose load according to weight at 1 year and adult body mass index. (Numbers of men given in square brackets)

\begin{tabular}{lcccc}
\hline \multirow{2}{*}{$\begin{array}{l}\text { Adult body } \\
\text { mass index } \\
\left(\mathrm{kg} / \mathrm{m}^{2}\right)\end{array}$} & \multicolumn{4}{c}{ Weight at 1 year in $\mathrm{lb}(\mathrm{kg})^{\star}$} \\
\cline { 2 - 5 } & $\begin{array}{c}\leqslant 21 \cdot 5 \\
(\leqslant 9 \cdot 75)\end{array}$ & $\begin{array}{c}-23 \cdot 5 \\
(-10 \cdot 66)\end{array}$ & $\begin{array}{c}>23 \cdot 5 \\
(>10 \cdot 66)\end{array}$ & Total \\
\hline$\leqslant 25 \cdot 4$ & $6 \cdot 6[45]$ & $6 \cdot 1[39]$ & $5 \cdot 8[36]$ & $6 \cdot 2[120]$ \\
-28 & $6 \cdot 7[47]$ & $6 \cdot 9[44]$ & $5 \cdot 9[36]$ & $6 \cdot 5[127]$ \\
$>28$ & $7 \cdot 7[39]$ & $7 \cdot 4[43]$ & $6 \cdot 6[41]$ & $7 \cdot 2[123]$ \\
\hline Total & $7 \cdot 0[131]$ & $6 \cdot 8[126]$ & $6 \cdot 1[113]$ & $6 \cdot 6[370]$
\end{tabular}

$\star$ Original measurements were expressed in $\mathrm{lb}$ and were rounded. Geometric standard deviation of plasma glucose $=1 \cdot 4$.

TABLE VII-Geometric mean plasma 32-33 split proinsulin concentration (pmolll) according to weight at 1 year and adult body mass index. (Numbers of men given in square brackets)

\begin{tabular}{lcccc}
\hline \multirow{2}{*}{$\begin{array}{l}\text { Adult body } \\
\text { mass index } \\
\left(\mathrm{kg} / \mathrm{m}^{2}\right)\end{array}$} & \multicolumn{4}{c}{ Weight at 1 year in $\mathrm{lb}(\mathrm{kg})^{\star}$} \\
\cline { 2 - 5 } & $\begin{array}{c}\leqslant 21 \cdot 5 \\
(\leqslant 9 \cdot 75)\end{array}$ & $\begin{array}{c}-23 \cdot 5 \\
(-10 \cdot 66)\end{array}$ & $\begin{array}{c}>23 \cdot 5 \\
(>10 \cdot 66)\end{array}$ & Total \\
\hline$\leqslant 25 \cdot 4$ & $2 \cdot 5[57]$ & $2 \cdot 2[56]$ & $2 \cdot 1[49]$ & $2 \cdot 2[162]$ \\
-28 & $3 \cdot 2[57]$ & $3 \cdot 6[49]$ & $3 \cdot 1[41]$ & $3 \cdot 3[147]$ \\
$>28$ & $4 \cdot 8[48]$ & $3 \cdot 8[59]$ & $3 \cdot 9[52]$ & $4 \cdot 1[159]$ \\
\hline Total & $3 \cdot 3[162]$ & $3 \cdot 1[164]$ & $2 \cdot 9[142]$ & $3 \cdot 1[468]$ \\
\hline
\end{tabular}

* Original measurements were expressed in $\mathrm{lb}$ and were rounded. Geometric standard deviation of plasma $32-33$ split proinsulin $=2 \cdot 1$.

above the median had impaired glucose tolerance. Only $5 \%$ of the men $(3 / 64)$ who were above the median for early weights and below the median for body mass index had impaired tolerance. The corresponding figures for diabetes were $15 \%$ and $2 \%(8 / 53$ and $1 / 64)$. The study sample comprised $40 \%$ of men who were born in east Hertfordshire and still living there. As our analysis was based on internal comparisons the selection of the sample would introduce bias only if the relations between early growth and plasma glucose, insulin, and proinsulin concentrations were different in those selected and not selected. This is unlikely. The same relations were found in each social class and each body mass group (tables VI and VII).

The correlation of birth weight and weight at 1 year with glucose intolerance might result from a single influence acting prenatally which reduces fetal growth and continues to affect infant growth. The mechanisms which link low fetal and infant growth rates with adult glucose intolerance are still a matter for speculation. We know, however, that much of the development of the islets of Langerhans occurs in utero. ${ }^{11}$ The exact timing of islet formation differs among species. In rats the numbers of islets increase rapidly in the last four to six days of intrauterine life. In humans $\beta$ cell mass increases more than 130 -fold between the 12 th intrauterine week and the fifth postnatal month.

Overnutrition during intrauterine life is known to influence $\beta$ cell development, in that diabetes during pregnancy-which has been likened to overnutrition-leads to $\beta$ cell hyperplasia in the fetus. ${ }^{12}$ There are few studies of the effects on $\beta$ cell development of undernutrition during early life. In rats weaned on to a low protein diet for only three weeks the insulin response to glucose was permanently impaired. This led to the suggestion "that early malnutrition may predispose to diabetes." ${ }^{\prime 13}$ Infants who are small for dates have fewer $\beta$ cells. ${ }^{14}$ There are conflicting reports on whether the $\beta$ cell mass is reduced in patients with non-insulin dependent diabetes. ${ }^{11}$ In one study, however, in which diabetic patients were compared with people of the same weight their $\beta$ cell mass was found to be lower. ${ }^{15}$

\section{A WORKING HYPOTHESIS}

As a working hypothesis it seems reasonable to propose that nutritional and other factors determining fetal and infant growth influence the size and function 
of the adult pancreatic $\beta$ cell complement. Plasma concentrations of 32-33 split proinsulin were higher in men with lower weight at 1 year (table $\mathrm{V}$ ). A raised plasma 32-33 split proinsulin concentration may indicate production of insulin by a comparatively small complement of $\beta$ cells. Whether and when non-insulin dependent diabetes supervenes will be determined by the rate of attrition of $\beta$ cells with aging and by the development of insulin resistance, of which the most important known determinant is obesity. An alternative explanation of the raised $32-33$ split proinsulin concentration is that it reflects increased insulin production secondary to insulin resistance. Further experiments are planned to investigate these possibilities or indeed whether processes leading to poor fetal and infant growth might lead to a combination of insulin deficiency and resistance.

An attractive feature of this explanation is that it provides an alternative to the "thrifty genotype" hypothesis. ${ }^{16}$ This hypothesis suggests that the high incidence of diabetes in Western or recently affluent societies results from the existence of diabetogenic genes which confer a survival advantage in conditions of subsistence living. We suggest that diabetes is a consequence of poor nutrition during critical periods of fetal life and infancy with consequent impaired development of $\beta$ cell function. If poor nutrition continues the reduced ability to produce insulin is not a disadvantage. It becomes so only if nutrition becomes abundant, when increased demand for insulin outstrips the capacity for production. Ethiopian Jews who migrated to Israel experienced a change from poor to abundant nutrition and had a subsequent high incidence of diabetes. ${ }^{17}$ The long term effects of poor nutrition during early life may depend on the nature, timing, and intensity of deprivation, which will determine the specific tissues in which development is impaired. This phenomenon may underlie several Western diseases other than diabetes, most importantly ischaemic heart disease. ${ }^{18}$

Consistent with other studies, ${ }^{19}$ we have found that plasma glucose concentrations are strongly related to blood pressure levels independently of body mass index. Blood pressure was inversely related to birth weight, as has also been found before. ${ }^{2}$ The association between blood pressure and 32-33 split proinsulin concentrations indicates that similar influences may impair vascular and pancreatic islet cell development in utero. The association of hypertension, non-insulin dependent diabetes, and hyperlipidaemia has been called syndrome X. ${ }^{20}$ Insulin resistance has been proposed as the link between these abnormalities. Our study, however, raises the possibility that retarded intrauterine growth may be the link.

Our findings are open to the interpretation that a genetically determined deficiency of insulin production is manifested by growth failure in early life long before the onset of adult glucose intolerance. The high concordance of non-insulin dependent diabetes in monozygotic twins is often cited as strong evidence that the disorder is genetically controlled. ${ }^{21}$ Because maternal physique and nutrition have such a strong influence on fetal and infant growth we favour an environmental explanation of our findings. This would necessarily put in question the genetic interpretation of concordance in monozygotic twins. The strong associations which we report suggest that research directed towards the causes of non-insulin dependent diabetes should examine the development of the pancreas in fetal life and infancy and the nutritional and other influences which regulate it.

We are grateful to all the men who gave us their time; to Hertfordshire County Archives, which preserved the records; and to the staff of the NHS Central Register, Southport, and Hertfordshire District Health Services Authority, who helped trace the men. We thank Dr I Clarke for much local help. The fieldwork was organised by A Lee and carried out by $\mathrm{P}$ Harwood, S Haynes, P Howell, R Rosenthal, and S Wolfe. B Alpha, M Brown, N J Crowther, A E SchneiderDarlinson, and D Wong gave technical assistance. We thank staff of the NHS section of the department of clinical biochemistry, Addenbrooke's Hospital, for glucose analyses, and B Newland, of Princess Alexandra Hospital, Harlow, fo storing specimens. The study was funded by the MRC, the Dunhill Medical Trust, the Wessex Medical Trust, the British Diabetic Association, and Lilly Research Laboratories.

1 Barker DJP, Winter PD, Osmond C, Margetts B, Simmons SJ. Weight in infancy and death from ischaemic heart disease. Lancet 1989;ii:577-80. 2 Barker DJP, Bull AR, Osmond C, Simmonds SJ. Fetal and placental size and risk of hypertension in adult life. BMF 1990;301:259-62.

3 Fuller JH, Shipley MJ, Rose G, Jarrett RJ, Keen H. Coronary heart disease risk and impaired glucose tolerance. Lancet 1980;i:1373-6.

4 Modan M, Halkin H, Almog S, Lusky A, Eshkol A, Shefi M, et al. Hyperinsulinemia: a link between hypertension, obesity and glucose intolerance. F Clin Invest 1985;75:809-17.

5 Sobey WJ, Beer SF, Carrington CA, Clark PMS, Frank BH, Gray IP, et al. Sensitive and specific two-site immunoradiometric assays for human insulin proinsulin, 65-66 split and 32.33 split proinsulins. Biochem f 1989;260: 535-41.

6 Temple RC, Carrington CA, Luzio SD, Owens DR, Schneider AE, Sobey WJ et al. Insulin deficiency in non-insulin dependent diabetes. Lancet 1989; 293-5.

7 Office of Population Censuses and Surveys. Classification of occupations 1980 London: HMSO, 1980

8 Kunst A, Draeger B, Ziegenhorn J. UV-methods with hexokinase and glucose6-phosphate dehydrogenase. In: Bergmeyer HU, ed. Methods of enzymati 6-phosphate dehydrogenase. In: Bergmeyer HU, ed. Methods of enzyma

9 Johannsson A, Stanley CJ, Self CH. A fast highly sensitive colorimetric enzyme immunoassay system demonstrating benefits of enzyme amplifications in clinical chemistry, Clin Chim Acta 1985;148:119-24.

10 Harris MI, Hadden WC, Knowler WC, Bennett PH. Prevalence of diabetes and impaired glucose tolerance and plasma glucose levels in US population aged 20-74 years. Diabetes 1987;36:523-34.

11 Hellerström C, Swenne I, Andersson A. Islet cell replication and diabetes. In Lefebvre PJ, Pipeleers DG, eds. The pathology of the endocrine pancreas in diabetes. Heidelberg: Springer Verlag, 1988:141-70.

12 Freinkel N. Of pregnancy and progeny. Diabetes 1980;29:1023-39.

13 Swenne I, Crace CJ, Milner RDG. Persistent impairment of insulin secretory response to glucose in adult rats after limited period of protein-calorie malnutrition early in life. Diabetes 1987;36:454-8.

14 Van Assche FA, Aerts L. The fetal endocrine pancreas. Contrib Gynecol Obstet 1979;5:44-57.

15 Klöppel G, Löhr M, Habich K, Oberholzer M, Heitz PU. Islet pathology and pathogenesis of type 1 and type 2 diabetes revisited. Survey and Synthesis of Pathology Research 1985;4:110-25.

16 Thrifty genotype rendered detrimental by progress? [Editorial]. Lancet 1989;ii:839-40.

17 Cohen MP, Stern E, Rusecki Y, Zeidler A. High prevalence of diabetes in young adult Ethiopian immigrants to Israel. Diabetes 1988;37:824-8.

18 Barker DJP. The intrauterine origins of cardiovascular and obstructive lung disease in adult life. $f R$ Coll Physicians Lond 1991;25:129-33.

19 Stamler J, Rhomberg P, Schoenberger JA, Shekelle RB, Dyer A, Shekelle S, et al. Multivariate analysis of the relationship of seven variables to blood pressure: findings of the Chicago Heart Association detection project in industry, 1967-1972. J Chronic Dis 1975;28:527-48.

20 Reaven GM. Role of insulin resistance in human disease. Diabetes 1988;37: 1595-607.

21 Newman B, Selby JV, King M-C, Slemenda C, Fabsitz R, Friedman GD. Concordance for type 2 (non-insulin-dependent) diabetes mellitus in male twins. Diabetologia 1987;30:763-8.

(Accepted 14 August 1991) 